Milan Beslać

\title{
Serbia: A factory without a roof
}

\begin{abstract}
Agriculture deals with the exploitation of the earth and the cultivation and breeding of useful plants and animals. The manufacture of vegetable and animal products and their processing at the primary level provides food for humanity and human survival on earth. Serbia is, in respect of its geographical position and agricultural potential, an agricultural country. The author seeks in this article to show that being an agricultural and agrarian country is neither wonder nor a national disgrace. In contrast, Serbia has potential in its agricultural soil and that this a source of the competitive advantage of which each country must take advantage. The author also recognises that, every day, thousands of people, many of whom are children, die of hunger and, for that reason, it is our national and social responsibility to produce food wherever possible. Concluding with an overview of the industry's strengths, weaknesses, opportunities and threats, the author contributes a perspective on the strategy that needs to be adopted to ensure Serbia plays to its potential in this area.
\end{abstract}

Keywords: agriculture, food, potential, competitive advantage, yield, irrigation and drainage systems, productivity, fragmentation, subsidies, Common Agricultural Policy, EU accession, land purchase, rural re-population

\section{Introduction}

In the world in 1960, there were three billion people and, since 2011, the Earth has been inhabited by seven billion people. This number is constantly increasing and it can be anticipated that, by 2030, the Earth's population will have grown to eight billion and to about nine billion people by 2050 . One of the conditions essential to the continuation of human life is the production of food: thus, very important tasks have been set for agricultural production in the future.

Agricultural production is a specific set of production tasks which largely depends on natural factors such as the scope and the quality of the soil; the topographical relief and configuration of the land; the climate; and so on (Frohber, 2005). Agricultural production involves a relatively long cycle, given the necessary combination of the manufacture of various types of products whose cycles of production and the time of the collection of revenues in respect of these do not match. The functions of agriculture are multi-dimensional and, in one sentence, it can be said that agriculture maintains life on Earth. In fact, without agriculture there is no food for humans, and without food there is no life. Consequently, the importance of agriculture is understandable.

Across the globe, there is a huge number of people who lack food. This means that all surpluses can be exported - and not just any surplus but that produced by the standards of importing countries. 
Agricultural production in advanced countries continues to be heavily subsidised. Subsidies, on the one hand, motivate farmers towards agricultural production; but, on the other, affect the falling prices for these products and their export to less-developed and developing countries.

Serbia has, for decades, been an agrarian country. Industrialisation after World War II saw to it that the number of residents who were engaged in agriculture reduced over a thirty-year period by 54 percentage points (in 1948, $73 \%$ of the population dealt with agriculture; while, in 1981, this had dropped to just $19 \%$ ). Such a decrease in agricultural population has taken a lot more time in other countries (in the US and Sweden, 90 years; in France, 100 years; in Japan, 73 years; in Denmark, 130 years; etc.).

In Serbia, agricultural production continues to occupy a position which is far below its real possibilities and potential.

\section{Agricultural potential in Serbia}

The country of Serbia is, regarding its geographical position, part of eastern and central Europe. The northern part of the country belongs to central Europe, where the Pannonian Plain is located. This part is most commonly called 'the granary of Europe'. Through the region of the Pannonian Plain flow two major rivers: the Danube (588 $\mathrm{km})$; and the Tisza $(168 \mathrm{~km})$ that meets with the Sava $(206 \mathrm{~km})$, the third large river, near Belgrade. In addition to these, three major Morava rivers also flow through Serbia (the Great $(185 \mathrm{~km})$; the West Morava $(308 \mathrm{~km})$; and the South Morava $(295 \mathrm{~km})$ ), as well as the Ibar $(272 \mathrm{~km})$, the Timok $(202 \mathrm{~km})$, the Begej $(75 \mathrm{~km})$, the Nišava $(151 \mathrm{~km})$, the Tamis $(118 \mathrm{~km})$ and the Drina $(220 \mathrm{~km})$.

Serbia is the land mass of the Balkans peninsula, surrounded by warm seas (the Adriatic, the Aegean and the Black Sea) and leaning in the north to the European continent.

In addition to the geographic location, the climate of Serbia is also influenced by its relief. It can be said that, in Serbia, there is a continental climate in the north; a moderate continental climate in the south; and a mountain climate in the high mountains. Winters in Serbia are short, cold and snowy while summers are warm. The average annual rainfall is $896 \mathrm{~mm}$. Most of the rainfall is in May and June, while the driest months are February and October.

In the northern part of Serbia is the autonomous province of Vojvodina $\left(21500 \mathrm{~km}^{2}\right.$ $-24.3 \%$ of Serbia) (Statistical Yearbook of the Republic of Serbia, 2011). Most of the territory of Vojvodina is very good quality arable land. Thus, the potential of Serbian agricultural production is located in Vojvodina; but not only in Vojvodina, such potential is also present in other parts of Serbia.

The Republic of Serbia is located in the most favourable area of northern latitude, with four seasons and four climates. Therefore, there are a very favourable natural conditions, suitable soil and climate for the successful development of agricultural production. The natural conditions allow for the development of crop and livestock agricultural production.

Until the Second World War, Serbia was an agrarian country: over $80 \%$ of its population was located in rural areas of the country and living a traditional way of life 
(Miladin and Danilo, 2010). The life of almost every resident was reduced to possession and family, village, church and friends. World War II, and the post-war period in particular, given the period of socialism and communism, destroyed the rural areas and the family-based systems of agriculture as a result of the so-called industrialisation and the taking of the land of peasants by the state. All this resulted in a departure of the population from the countryside to the cities.

Serbia remains a poor country; and the majority of the income of each employee (over $80 \%$ ) goes on the cost of food.

According to the first results of the census of agriculture of Serbia in 2012, Serbia has the following agricultural resources:

Table 1 - Summary of the agricultural potential of the Republic of Serbia

\begin{tabular}{|c|l|c|}
\hline Category & \multicolumn{1}{|c|}{ Description } & Size \\
\hline 1 & Agricultural land & 5113000 ha \\
\hline 2 & Arable land & 3355859 ha \\
\hline 3 & Total number of agricultural holdings & 631122 \\
\hline 3.1 & Family holdings & $628555(99.59 \%)$ \\
\hline 3.2 & Holdings of legal entities and entrepreneurs & $2567(0.41 \%)$ \\
\hline 4 & Number of double-axle tractors & 408734 \\
\hline 5 & Faculties of agriculture & 3 \\
\hline 6 & Other faculties & 30000 \\
\hline 7 & Agricultural institutes & $\begin{array}{l}\text { Graduates of agricultural engineers of different } \\
\text { specialities }\end{array}$ \\
\hline 8
\end{tabular}

Source: RZS

It is well-known that the economic development of a country should be based on the use of its own specific resources, i.e. those resources that the country possesses in abundance (Stojanović et al, 2010). The country of Serbia abounds in agricultural resources and, therefore, its strategic branch should be agricultural production. In contrast, according to the potential, agricultural production is participating in creating GDP neither to the extent that it possibly could do nor to the extent that is required. 
Table 2 - Summary of the participation of agriculture in GDP in the Republic of Serbia

\begin{tabular}{|c|c|c|c|c|c|c|c|c|}
\hline & \multicolumn{4}{|c|}{ In millions of RSD } & \multicolumn{4}{c|}{ Structure in \% } \\
\cline { 2 - 9 } & $\mathbf{2 0 0 8}$ & $\mathbf{2 0 0 9}$ & $\mathbf{2 0 1 0}$ & $\mathbf{2 0 1 1}$ & $\mathbf{2 0 0 8}$ & $\mathbf{2 0 0 9}$ & $\mathbf{2 0 1 0}$ & $\mathbf{2 0 1 1}$ \\
\hline Agriculture & 237474 & 218005 & 245127 & 292918 & 8.9 & 8.0 & 8.5 & 9.1 \\
\cline { 1 - 8 } GDP (000) & 2661 & 2720 & 2882 & 3209 & & & & \\
\hline
\end{tabular}

Source: RZS

Considering the agricultural potential, the share of agricultural production in GDP is not sufficient. This situation is influenced by various factors, primarily the lack of consistent agricultural policies, an inadequate agricultural budget and insufficient use of irrigation and drainage systems. The scientific technical institutions are producing high-quality seeds adapted to the climate and other conditions in Serbia; yet, the yield is not satisfactory. Almost every year, a decrease in yield is affected by the meteorological conditions. The lack of irrigation and drainage systems is significantly and in every year affecting the yield, both in terms of quantity and of quality (Zakić et al, 2010).

\section{Irrigation and drainage}

The hydro-system Danube-Tisza-Danube Canal (DTD) was completed in 1977. This is a unique canal network connecting the Danube and the Tisza and represents a hydro-technical system for internal water drainage, irrigation, flood control, water supply, the drainage of used water, navigation, tourism, fishing and forestry. The DTD hydro-system, with natural and partially-reconstructed water courses, is $960 \mathrm{~km}$ in length, of which $600 \mathrm{~km}$ are navigable. Its network connects eighty villages in Vojvodina; within the system, there are 23 floodgates, five security floodgates, followed by 15 shipping locks, five major pumping stations and 86 bridges (64 road, 21 rail and one pedestrian). This canal is an invaluable resource for agricultural production. The system is designed according to the system of connected vessels which means that, as long there is water in the Danube and Tisza, the channel does not change the water level.

The most important function of the hydro-system is drainage and irrigation. The total amount of accepted and evacuated water is one million hectares in the area of Bačka and 250 million cubic meters per year in Banat. According to the project, the hydro-system can irrigate up to 510000 ha but, unfortunately, it currently irrigates only 30000 ha.

The construction of the DTD hydro-system saw the defensive lines in Vojvodina reduced from $502 \mathrm{~km}$ to $446 \mathrm{~km}$, while the flood defences were also drastically reduced.

The DTD hydro-system also has a very important role for industry as well, since it delivers forty million cubic meters of water to industry annually. The canal is also used for navigation and transport (the projected potential is seven million tons per year), receiving used water and protecting water quality; followed by forestry, fishing, nautical tourism and recreation. 
Why is this unique hydro-system, completed almost forty years ago, using only $5.9 \%$ of its potential? The reasons are several and include the state of Serbia in the last several decades not having an agricultural policy that required such a potential; nonagricultural production having assumed a dominant role in the past years; and agricultural policy having no permanent or continuing policy of subsidies and similar forms of motivation for farmers.

Results of agricultural policy

The results of agricultural policy in Serbia are evident if we analyse the amount of agricultural land owned by an agricultural household:

Table 3 - Number of agricultural holdings and area of used agricultural land

\begin{tabular}{|c|c|c|c|c|c|c|c|c|}
\hline Country & $\begin{array}{l}\text { No } \\
\text { land }\end{array}$ & $\begin{array}{l}\text { Up to } \\
2 \text { ha }\end{array}$ & $\begin{array}{c}2.01- \\
5 \mathrm{ha}\end{array}$ & $\begin{array}{l}5.01- \\
10 \text { ha }\end{array}$ & $\begin{array}{c}10.01- \\
20 \text { ha }\end{array}$ & $\begin{array}{c}20.01- \\
50 \text { ha }\end{array}$ & $\begin{array}{l}50.01- \\
100 \text { ha }\end{array}$ & $\begin{array}{l}\text { Over } \\
100 \text { ha }\end{array}$ \\
\hline \multirow[t]{2}{*}{ Serbia } & 9486 & 293667 & 184637 & 89749 & 32486 & 12922 & 4243 & 1365 \\
\hline & $1.5 \%$ & $46.7 \%$ & $29.4 \%$ & $14.4 \%$ & $5.1 \%$ & $2.1 \%$ & $0.6 \%$ & $0.2 \%$ \\
\hline \multirow{2}{*}{$\begin{array}{l}\text { EU-27 } \\
(000)\end{array}$} & 258 & 5608 & 2407 & 1303 & 901 & \multicolumn{2}{|c|}{1164} & 325 \\
\hline & $2 \%$ & $47 \%$ & $20 \%$ & $11 \%$ & $8 \%$ & \multicolumn{2}{|c|}{$9 \%$} & $3 \%$ \\
\hline \multirow[t]{2}{*}{ Austria } & 1080 & 16160 & 30220 & 26590 & 32590 & \multicolumn{2}{|c|}{40690} & 2850 \\
\hline & $0.7 \%$ & $10.76 \%$ & $20.1 \%$ & $17.70 \%$ & $21.70 \%$ & \multicolumn{2}{|c|}{$31.09 \%$} & $1.9 \%$ \\
\hline \multirow[t]{2}{*}{ Germany } & 1410 & 14260 & 11690 & 47310 & 63160 & \multicolumn{2}{|c|}{127690} & 33620 \\
\hline & $0.4 \%$ & $4.76 \%$ & $3.90 \%$ & $15.81 \%$ & $21.11 \%$ & \multicolumn{2}{|c|}{$42.68 \%$} & $11.23 \%$ \\
\hline \multirow[t]{2}{*}{ Spain } & 22500 & 270280 & 232800 & 141850 & 110960 & \multicolumn{2}{|c|}{160210} & 51190 \\
\hline & $2.27 \%$ & $27.30 \%$ & $23.51 \%$ & $14.33 \%$ & $11.21 \%$ & \multicolumn{2}{|c|}{$16.28 \%$} & $5.17 \%$ \\
\hline \multirow[t]{2}{*}{ Italy } & 5290 & 819360 & 357670 & 186150 & 120120 & \multicolumn{2}{|c|}{116820} & 15490 \\
\hline & $0.3 \%$ & $50.55 \%$ & $22.06 \%$ & $11.48 \%$ & $7.41 \%$ & \multicolumn{2}{|c|}{$7.20 \%$} & $0.95 \%$ \\
\hline \multirow[t]{2}{*}{ Hungary } & 42790 & 412740 & 46060 & 26540 & 19430 & \multicolumn{2}{|c|}{21800} & 7450 \\
\hline & $7.41 \%$ & $71.55 \%$ & $7.98 \%$ & $4.60 \%$ & $3.36 \%$ & \multicolumn{2}{|c|}{$3.77 \%$} & $1.29 \%$ \\
\hline \multirow[t]{2}{*}{ Holland } & 1700 & 8000 & 11000 & 10260 & 10820 & \multicolumn{2}{|c|}{28350} & 2210 \\
\hline & $2.35 \%$ & $11.06 \%$ & $15.21 \%$ & $27.69 \%$ & $14.96 \%$ & \multicolumn{2}{|c|}{$39.20 \%$} & $3.05 \%$ \\
\hline \multirow[t]{2}{*}{ Greece } & 5910 & 338430 & 172650 & 83390 & 43430 & \multicolumn{2}{|c|}{29630} & 1440 \\
\hline & $0.8 \%$ & $50.14 \%$ & $25.58 \%$ & $12.35 \%$ & $6.43 \%$ & \multicolumn{2}{|c|}{$4.39 \%$} & $0.21 \%$ \\
\hline
\end{tabular}

Sources: RZS Agricultural Census in 2012 in the Republic of Serbia, first results (for Serbia); Eurostat (for EU-27 and EU countries) 
It is often said that insufficient agricultural production is the result of a fragmentation of proprietary property. However, these data show that this is not quite true. Table 3 shows that $67 \%$ of agricultural holdings in the EU are based on land not exceeding 5 ha, while $11 \%$ of households own land from 5 to 10 ha; $8 \%$ from 10 to 20 ha; and $9 \%$ from 20 to 100 ha. In comparison, in Serbia, $77 \%$ of agricultural households have land not exceeding 5 ha. Other countries in Europe are not in any better position. Thus, in Greece $75 \%$ of households have land up to 5 ha; in Hungary it is $80 \%$; in Italy, which creates extraordinary results in agriculture, $72 \%$ of households own land up to $5 \mathrm{ha}$; and in Spain the figure is up to $50 \%$. In Germany and Austria, the proportion is much lower (about $8 \%$ in Germany, while in Austria it is about $30 \%$ ) (Eurostat, 2011).

These data indicate that the size of agricultural estate is not fully correlated with the efficiency of a country's agricultural production. Specifically, this is about competitiveness and increases in productivity, as well as motivation towards agricultural production and the relationship of the state towards the agricultural industry.

Low productivity and a lack of competitiveness are also evident from the data in Table 4. Despite its extraordinary potential, Serbia is not a modern agricultural country. Today, a Serbian farmer produces food for fifteen people whereas the figures are much higher elsewhere, rising to 152 in Germany, with the EU average being between fifty and eighty people. Imagine the paradox that Slovenia, in which the natural conditions are not anywhere near as good as regards agricultural production as they are in Serbia, and which is not part of the 'granary of Europe', can produce food for 25 people; a better record of productivity than Serbia.

Table 4 - Population fed per active famer, selected countries

\begin{tabular}{|l|c|}
\hline Country & Population \\
\hline EU & 75 \\
\hline Serbia & 15 \\
\hline France & 77 \\
\hline Germany & 152 \\
\hline Austria & 56 \\
\hline Slovenia & 25 \\
\hline
\end{tabular}

Source: Eurostat

Measures to improve competitiveness related to increases in productivity, quality and quantity of production, etc.

In order to increase competitiveness, it is necessary to take measures such as reducing the cost of production in order to achieve price competitiveness; improving the quality of products according to pre-determined standards; guiding and encouraging manufacturers to produce better varieties; and conducting marketing activities in order to create trademarks and brands in order to gain the trust of foreign consumers (Zakić and Stojanović, 2008). 
Certainly, competitive advantage should be achieved by using the positive differences implied by the available natural resources (climate, soil and water resources irrigation systems, etc.). It should be emphasised that the priority is to produce safe and healthy food, which also takes up a great deal of the sector's unused capacity.

\section{Analysis of agricultural production}

According to an analysis of Serbia's agricultural potential, these are the industry's major strengths and weaknesses, as well as the opportunities it has and the threats to which it must face up.

\section{Strengths}

These indicate that agricultural production has sufficient potential to be a leading economic sector. Agriculture needs to be among the leading industries due to its natural and acquired resources. The natural resources are the agricultural lands on which can be grown crops, vegetable crops, fruit, livestock, viticulture, apiculture, hunting, etc. For all these activities, the natural resources required for their development do exist. However, to lead to such a development, Serbia has to do no more than what developed countries do, which is to encourage and stimulate agricultural production in line with world standards. Thus, the state should determine the objective incentives and the level of stimulation, which should be certain over a long period. The state needs to regulate the parity of agricultural products. In this manner, a wide range of agricultural products will be secured and our manufacturers will not, every year, run off to another crop in the pursuit of higher profits. Creating the conditions for successful agricultural production would also create the conditions for the return of people to the land.

\section{Weaknesses}

The weaknesses of the sector have been identified for decades. In fact, there is no strategy of agricultural production; the measures taken in the area of encouraging and stimulation are short-run and completely unpredictable. There is no certainty for farmers and no pricing policy or fixed parities. Meanwhile, the lack of local investment in irrigation systems and drainage systems is a significant risk for the development of agriculture.

\section{Opportunities}

Agricultural production must be improved. This will open up the space for education and the employment of a large number of experts from scientific and other professional institutions, as well as other individuals. The 'granary of Serbia' has a welldeveloped infrastructure for providing irrigation and drainage, as we have seen. However, the Republic of Serbia has, for years, ignored irrigation systems as products depended exclusively on 'God', or meteorological conditions, with the result that investment is necessary for the treatment and digging of new canals that connect agricultural land with the DTD canal, as well as the construction and installation of irrigation systems and drainage systems. This will result in long-term beneficial effects because our fields would not then depend only on the May and June rains and spring floods. At the 
same time as providing irrigation systems, the conditions for multiple annual harvests would also be provided for.

The production of healthy food and food without genetically modified organisms presents a clear opportunity for agriculture.

Industrial production should be developed, but the dominant form should be production that ensures the development and increase of agricultural productivity, such as tractors and engines, combines and other agricultural machinery and equipment, and the manufacture of machinery and equipment for the processing of agricultural products. In that way, the processing industry would also be stimulated so that Serbia would not predominantly export primary products but processed ones.

\section{Threats}

The threats facing the industry are very sharp and very important as regards the further development of agriculture. The main threat to the liberalisation of agricultural production is that domestic agricultural production will not, for a long time, be competitive with agricultural production in the developed world, although state policy has imposed a complete liberalisation of market competition. A particular problem is the liberalisation of the purchase of agricultural land pursuant to ratification of the SAA (Stabilisation and Association Agreement) by all EU members (only Lithuania is yet to ratify the SAA). Four years after the ratification of the SAA, customers in the EU will, under the same conditions, be able to buy Serbian fields alongside our citizens. In practice, it may happen that privileged EU buyers do not realise this opportunity prior to the entry of Serbia into the EU, i.e. before we can access all the pre-accession funds.

Such a situation was not the case with any of the thirteen new members of the EU, none of whom negotiated such short deadlines. None of the recently admitted members of the EU allowed this until it had entered into full membership; and some have retained a moratorium on the sale of land even after entering EU membership. Even though Croatia has been a member for a few months, Croatia is still negotiating on the issue of the sale of land.

Our government has realised what a mistake had been made and intends to seek an amendment of the SAA in this area, but this has not yet been done with total certainty in the pursuit of further negotiations. A personal view is that, if it comes to negotiation on this issue, nothing will change. Unless the government makes a decision on the production of GMOs, then this is indeed a major threat to the further development of agricultural production in Serbia.

\section{Conclusion}

Agriculture as an economic branch has great significance in the overall economic life of any country. The Republic of Serbia has very favourable natural resources for the development of each type of agricultural production (agriculture, horticulture, animal husbandry, viticulture, apiculture, etc.). These natural resources have not, in recent decades, been particularly well-used so today Serbia is an under-developed country. In 
addition to this, Serbia still imports milk, meat and grains, almost all agricultural products in fact, despite having granary and pasture.

In order to cut import dependence in the sphere of agriculture, it should be acknowledged that Serbia is an agricultural country and that this not too hard nor a bad thing. Then, it needs to make a strategy for agricultural development which must be defined so as to stimulate agricultural production, encourage a return to the villages and providing a significant share of agriculture in GDP.

It is necessary to use the existing infrastructure of the DTD canal and provide for the irrigation and drainage of agricultural and other land. Industrial development should also be oriented around support for the development of agriculture.

\section{References}

Frohber, K (2005) Special Issue Plenary Paper from XI EAAE Congress, Copenhagen, 32(3): 229-300.

Miladin, Š and T. Danilo (2010) Agrarian economy of Serbia and European integration: the (un)suitability of a mutual application of the Interim Trade Agreement: a thematic anthology Serbian Association of Agricultural Economists: Belgrade.

Stojanović, Ž, G. Ognjanov and J. Filipović (2010) 'Traditional food and its implications for the development of rural tourism in Serbia' Agricultural Economics Vol. LVII, EP2010 (57) SI-2.

Zakić, Z, G. Rikalović and Ž. Stojanović (2010) 'Rural development in the focus of the new industrialization' Economic Perspectives 15(2).

Zakić, Z and Ž. Stojanović (2008) Agricultural Economics Faculty of Economics: Belgrade.

Eurostat pocketbooks: Agriculture, fishery and forestry statistics: Main results 2010-11, ISSN 1977-2262.

European Commission - Agriculture and Rural Development policies http://ec.europa.eu/agriculture/

Statistical Yearbook of the Republic of Serbia, 2011. 